\title{
What makes lady beetles effective natural enemies in preventative biological control?
}

\author{
Natalia Belyakova ${ }^{1}$, and Yulia Polikarpova \\ All-Russian Institute of Plant Protection, 196608, St. Petersburg, Russia
}

\begin{abstract}
Based on the reconsideration of traditional criteria for assessing the efficacy of natural enemies, the screening of coccinellids for preventative control of aphids was conducted. The result suggests that there is no causation between the female size (weight) and the reproductive potential of the tested species. Considering that size does not matter in preventative releases, it is more cost-effective to produce small lady beetles. Essential and non-essential ecological knowledge for the efficacy assessment is discussed.
\end{abstract}

\section{Introduction}

The use of insects and mites as biological control agents (BCA) is the safest and most effective method of plant protection in greenhouses and organic farming, where the use of chemical pesticides is prohibited or limited. Releases of entomophagous arthropods (natural enemies of pests) are an essential element of environmentally friendly technologies for the growing of plants. More than 360 species of natural enemies are widely used for biological pest control [1]. Most of them are Hymenoptera parasitoids with narrow host-specialization, which keeps them focused on target pests and consequently makes hymenopteran BCA effective. Polyphagous bugs (Miridae, Anthocoridae) are also widely used groups of natural enemies, the popularity of which has risen for the last decade, mostly because of their ability to survive in modern plant protection systems, which are based on preventative inoculation - release of BCA before pests have arrived. But the plant damages caused by mirid zoophytophagy partly limit their usage. Also, mirid and pirate bugs lay their eggs in plant tissues. This reproductive trait makes their mass rearing elaborate.

Another group of polyphagous predators, the coccinellids, can be perfectly used in preventative biocontrol. Lady beetles survive on substitute diets in the absence of the target pest; they have no close connection with plants so they cannot cause any damage. But currently their market value would be considered small: only hundreds or thousands of individuals are sold per week. In contrast, hymenopterous parasitoids are released by the millions of individuals weekly [2].

Only 26 coccinellid species (about $7 \%$ of all available commercial BCA) are used worldwide in augmentative biological control. Recently, lady beetles have been covering less than $1 \%$ of the market volume of BCA [3]. For instance, indoors they are mostly used

${ }^{1}$ Corresponding author: biocontrol@vizr.spb.ru 
for augmentaton on the larval stage as «live insecticide» for eliminating aphid hot spots on green vegetables, cucumber or eggplant. Such a narrow approach partly explains the small scale of coccinellid bioresources development. It is time to reconsider the significance of this group of predators. The benefits which lady beetles can bring to biocontrol systems might be much bigger than now.

In particular, aphidophagous coccinellids can be used on the adult stage for preventative control of virus-vectoring aphids on potato in greenhouses [4]. We consider that the same approach could be used indoors in general. To test this suggestion, we aimed our research at the screening of coccinellids for preventative control of aphids, including virus vectors on vegetable and ornamental cultures.

The obtained results of the coccinellid screening could provide a basement for the discussion about essential and non-essential ecological knowledge for efficacy assessment in general. The current approach to BCA screening is based on a comparative analysis of dozens of biological traits (so-called « criteria of efficacy »). However, the same BCA traits may have different significance depending on the circumstances of the application.

Taking lady beetles as an example, we search for a new approach that could bring some essential ecological information about the species together and let us find out what really makes coccinellids effective in biocontrol.

\section{Materials and methods}

As the sources for screening, we used natural coccinellids populations and the State bioresource collection of entomophagous which is maintained at All-Russian Institute of Plant Protection (VIZR).

Laboratory populations from the VIZR collection were used in experiments to assess the food preferences and the reproductive potential of promising ladybird species (Table 1).

Table 1. Entomophage Laboratory Cultures from VIZR Collection Coccinellidae Family

\begin{tabular}{|l|l|}
\hline \multicolumn{1}{|c|}{ Species } & \multicolumn{1}{c|}{ Laboratory Population Origin } \\
\hline Adalia bipunctata L. & Russia, St. Petersburg, 2018 \\
\hline Cheilomenes sexmaculata F. & Nepal, 2013, China, Hainan, 2017 \\
\hline Cycloneda sanguinea L. & Central America, Cuba, 1974 \\
\hline Harmonia axyridis Pallas & China, Chanchun, 2018 \\
\hline Harmonia dimidiata F. & South East of China, 1990; Nepal, 2013 \\
\hline Propylea japonica Thunb. & China, Chanchun, 2018 \\
\hline Propylea 14-punctata L. & Russia, St. Petersburg, 2018 \\
\hline
\end{tabular}

Green bugs (grain aphids) Schizaphis graminum Rond. and the eggs of grain moth Sitotroga cerealella Oliv., stuck with honey to thick paper cards, were used as a feed for imago and larvae. The traits were tested under temperatures $16^{\circ} \mathrm{C}$ and $24^{\circ} \mathrm{C}$, photoperiod $16: 8 \mathrm{~h} \mathrm{light/dark.}$

The integrated value of ladybird reproduction was calculated as the product of the egg volume multiplied by the ovarioles' number divided by the female insect weight.

The weight was tested just after the adult's emerged before feeding. So the beetles had no opportunity to eat or drink anything. It means that the tested weight reflects their size and could be considered as a measure of reproductive potential. The imago was weighed within 24 hours after emerging. Vibra HT-80CE scales with an accuracy of $\pm 0.0001 \mathrm{~g}$ were used. The sample number for each species was not less than 50 females. The egg volume was determined by the ellipsoid of revolution formula.

To determine the number of ovarioles, females were opened up under MBI-11 binocular in physiological solution. The number of ovarian tubes in the right and left ovaries in 
transmitted light was counted. The sample number for each species was not less than 20 females. The tested indicators error was calculated using Statistica v.9 statistical software package.

\section{Results and discussion}

The screening started with the analysis of lady beetle species, which are used currently in aphid control. We found 11 species, which are used around the world for aphid control (Table 2). They have been sold on the BCA market for many decades, which means there is no need to discuss issues related to production, marketing and registration. All these aspects have been were sorted out for these species by previous researchers. Our goal was to find traits which would make these species effective in the preventative control of pests and virus-vectoring aphids in particular.

In the first stage of the screening, we assessed food preference for target species, i.e. virus-vectoring aphids.

Table 2. Aphidophagous ladybirds feeding on aphids vectoring viruses

\begin{tabular}{|c|c|c|c|c|c|c|c|c|}
\hline \multirow[b]{2}{*}{ Coccinellid species $^{1}$} & \multirow[b]{2}{*}{$\begin{array}{l}\text { Region } \\
\text { where } \\
\text { used }^{1,2}\end{array}$} & \multicolumn{6}{|c|}{ Aphids vectoring viruses } & \multirow[b]{2}{*}{ 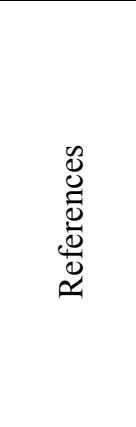 } \\
\hline & & 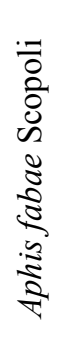 & 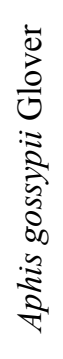 & 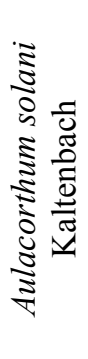 & 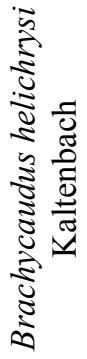 & 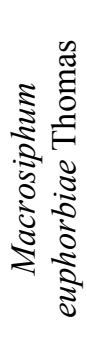 & 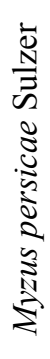 & \\
\hline Adalia bipunctata L. & $\mathrm{LA}, \mathrm{Ru}$ & $x$ & $x$ & $x$ & $x$ & $x$ & $x$ & {$[5-7]$} \\
\hline $\begin{array}{c}\text { Coccinella } \\
\text { septempunctata } \mathrm{L} .\end{array}$ & $\mathrm{Eu}$ & $x$ & $x$ & $x$ & $x$ & $x$ & $x$ & {$[5,7,8]$} \\
\hline $\begin{array}{c}\text { Cheilomenes } \\
\text { sexmaculata } \mathrm{F} \text {. }\end{array}$ & As & $x$ & $x$ & $x$ & $x$ & & $x$ & {$[9,10]$} \\
\hline Cycloneda sanguinea $\mathrm{L}$. & $\mathrm{Eu}, \mathrm{Ru}$ & $x$ & $x$ & & & $x$ & $x$ & {$[5,10]$} \\
\hline Eriopis connexa Germar & LA & & $x$ & & & $x$ & $x$ & {$[10,11]$} \\
\hline Harmonia axyridis Pallas & $\begin{array}{l}\text { NA, As, } \\
\text { Ru }\end{array}$ & $x$ & $x$ & $x$ & $x$ & $x$ & $x$ & $\begin{array}{c}{[6,12} \\
13]\end{array}$ \\
\hline Harmonia dimidiata $\mathrm{F}$. & $\mathrm{Eu}, \mathrm{Ru}$ & $x$ & $x$ & & & $x$ & $x$ & {$[8,9,14]$} \\
\hline $\begin{array}{l}\text { Hippodamia convergens } \\
\text { Guérin-Méneville }\end{array}$ & $\mathrm{Eu}$ & & $x$ & & & & $x$ & {$[10,15]$} \\
\hline $\begin{array}{c}\text { Hippodamia variegata } \\
\text { Goeze }\end{array}$ & $\mathrm{Au}$ & $x$ & $x$ & $x$ & $x$ & $x$ & $x$ & {$[8,9]$} \\
\hline $\begin{array}{c}\text { Propylea japonica } \\
\text { Thunb }\end{array}$ & As, $\mathrm{Ru}$ & & $x$ & & & & $x$ & {$[9,10]$} \\
\hline Propylea 14-punctata L. & $\mathrm{Eu}$ & $x$ & $x$ & & $x$ & $x$ & $x$ & {$[5,9,13]$} \\
\hline
\end{tabular}

All selected lady beetles feed on the green peach aphid (the main virus vector for vegetables). Five species consume $70-100 \%$ of targeted aphid species. C. sanguinea and H. dimidiata have a lower value (50-60\%) (Table 2). 
In general, all selected lady beetle species are suitable for further testing, which includes an estimation of the ability to survive on alternative food in the absence of pests or bridge periods of low pest presence. According to our data, seven species from the VIZR collection (Table 1) can feed on Sitotroga eggs in the adult and larval stages, which creates an opportunity to maintain their population in greenhouses in the absence aphids.

There are two main ways of applying the lady beetles in biological control: 1) release of larvae of II-III instars; 2) release of mature adults. In preventative inoculation, it is better to use adults, due to their good pest finding capacity, including flying ability, which is vital for single aphid tracing and catching. This means that high pest-kill ability (voracity), which increases with the predator's body size, is not so crucial in the preventative release of adults, as previously considered for the release of larvae in hot pest spots. So high pest-kill ability, which has been marked as an essential traits for BCA success, has became an unuseful criteia in the given circumstances.

If voracity and, consequently, size doesn't matter in preventative releases, it will be more cost-effective to produce small lady beetles, which is less time and resource consuming. The amount of the released BCA is calculated according to the fioor area of greenhouses, not to pest abundance. It makes usage of the small lady beetles much more rational.

On the next step of the screening we have selected five species from the VIZR collection: Ch. sexmaculata, C. sanguinea, A. bipunctata, P. 14-punctata and P. japonica, which are relatively small (imago weight $5-15 \mathrm{mg}$ ).

Body size is often connected with the biotechnological potential of BCA. So it was necessary to estimate potential losses in productivity of mass rearing for the selected smallsized species. The species were compared with an integral indicator, which reflects the female reproductive capacity (see Materials and Methods).

The result suggests that there is no causation between female size (weight) and the reproductive potential of the tested species (Fig. 1). For example, one of the small-sized species - Ch. sexmaculatus - is very close in the reproduction level to the biggest species H.dimidiata, despite the significant difference (six times) of their body weight (Fig.1). This example shows that some small lady beetles can be equal to big ones in their biotechnological potential.

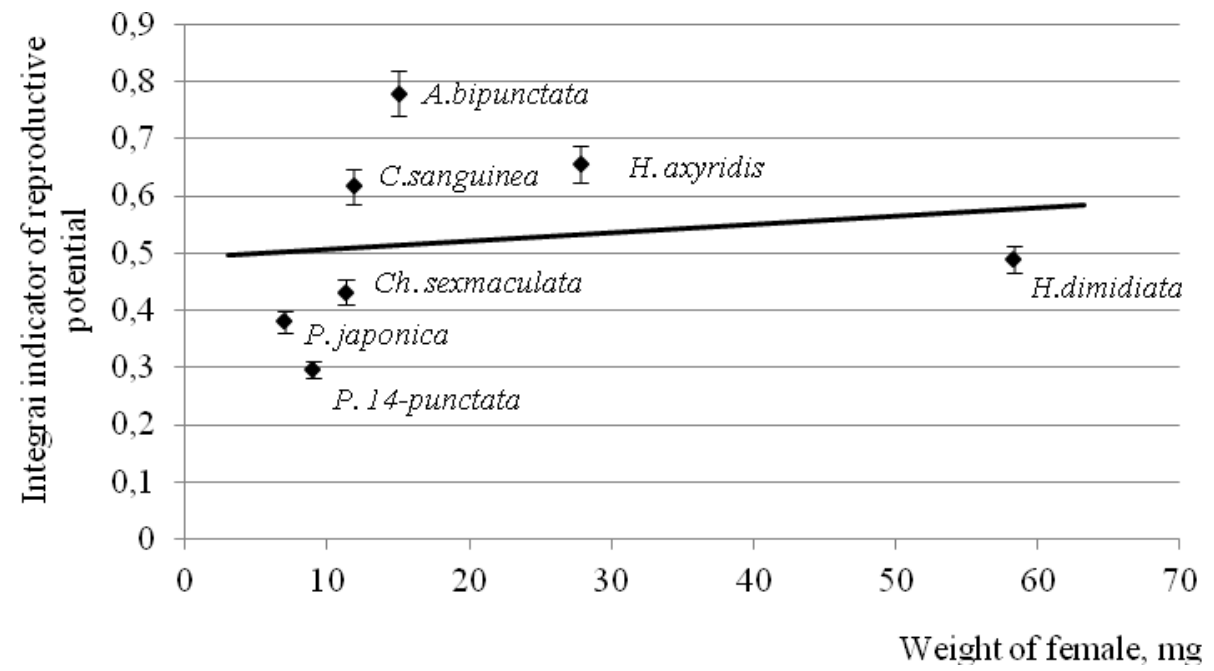

Fig. 1. Reproductive potential of aphidophagous lady beetles of different size classes 
Putting three reproductive traits (volume of egg, body mass, and ovariole number) in one indicator has simplified the process of competitive assessment and lets us find the most suitable species - Ch. sexmaculatus - according its food preferences, size and reproductive potencial.

In the future, the integration of single traits should become a basement of BCA screening. We need an approach that could bring all the information about the species together, process it mathematically, and summarize it all in one or two final indicators. The methodological basis for that would be the system of life strategies.

\section{Acknowledgements}

This research is carried out by a grant of Russian Science Foundation (Project 20-6647010).

\section{References}

1. J.C. van Lenteren, K. Bolckmans, J. Kohl, W. J. Ravensberg, A. Urbaneja, BioControl 63, 39-59 (2018) DOI: 10.1007/s10526-017-9801-4

2. J.C. van Lenteren, BioControl 57, 1-20 (2012) DOI: 10.1007/s10526-011-9395-1

3. R. Albajes, M. Lodovica Gullino, J.C. van Lenteren, Y. Elad, Integrated Pest and Disease Management in Greenhouse Crops (2020)

4. N.A. Belyakova, Yu.B. Polikarpova, Agric. Biol. 53, 140-150 (2018) DOI: 10.15389.2018.1.140eng

5. I. Hodek, H.F. van Emden, A. Honek, Ecology and Behaviour of the Ladybird Beetles (Coccinellidae) (2012) https://www.wiley.com/en-ru/Ecology+and+Behaviour+ of + the + Ladybird + Beetles $+($ Coccinellidae $)$-p-9781405184229

6. E.W. Riddick, Insects 8, 38 (2017) DOI:10.3390/insects 8020038

7. D.G. Stavridis, P.N. Deligeorgidis, N.P. Deligeorgidis, V. Greveniotis, E. Marnieri, C.G. Ipsilandis J. Adv. Res. Biol. Sci. 5, 294-300 (2018) DOI: 10.22192/ijarbs.2018.05.07.023

8. A.A. Khan, M.A. Shah, J. Entomol. Zool. Stud. 5, 189-203 (2017) DOI:10.18311/jbc/2019/22717

9. H.C. Chaudhary, R. Singh, J. Aphidology 25 \& 26, 13-30 (2012) https://www.researchgate.net/publication/270099568_Records_of the predators_of_aphids Homoptera_Aphididae in eastern_Uttar_Pradesh

10. C.A. Tavares, - Prey specialization in ladybirds: Iberorhyzobius rondensis, a potential biological control of Matsucoccus feytaudi. (Lisboa: ISA 2014) https://www.repository.utl.pt/bitstream/10400.5/7829/1/PHD\%20TESE_VERSAO FINAL . $\mathrm{pdf}$

11. W. Duarte, H.Arévalo, I. Polania, Open J. Anim. Sci. 3, 193-199 (2013) DOI: 10.4236/ojas.2013.33029

12. A. Vandereycken, D. Durieux, E. Joie, E Haubruge, F. Verheggen, BASE 16, 553563 (2012) https://popups.uliege.be/1780-4507/index.php?id=17009\&file=1\&pid=9256

13. C. Finlayson, A. Alyokhin, S. Gross, E. Porter, J. Insect Sci. 10, 1-10 (2010) DOI:10.1673/031.010.3101

14. https://nbair.res.in/Databases/Featured insects/Harmonia-dimidiata.php

15. R.B. Shrestha, M.N. Parajulee, Insect Sci. 20,778-788 (2012) DOI: 10.1111/j.17447917.2012.01583.x 